Joanna Malec

Pontifical University of John Paul II in Krakow

\title{
Anti-Christian violence in the Indian State of Orissa in 2008 in the reports of non-governmental organizations
}

In August 2008 India became a place of intense attacks on Christians. Orissa - the state located on the eastern coast of the Bay of Bengal - was the centre of these events and the most affected area was the Kandhamal District. ${ }^{1}$ The local and international media reported the facts of brutal beatings, murders, rapes and damages of Christians' properties as a single and new phenomenon in the history of India's tolerance in spite of the opinions of specialists that these attacks were not the first and probably not the least in this region. ${ }^{2}$ Only some Indian media attempted to present a deeper analysis based on the data flowing mainly from the NGOs and Christian organizations. After a few weeks Orissa ceased to be a subject of interest of public opinion and till now no official and reliable evaluation of the August events has been given.

${ }^{1}$ Apart from Khandamal the following districts in Orissa were affected: Boudh, Bhadrak, Bargarh, Cuttack, Gajapati, Ganjam, Koraput, Kalahandi, Naupada, Narbarangapur, Nayagarh, Sambalpur, and Rayagada according to the Christian Legal Association. See: Christian Legal Association, Report on Anti-Christian Violence in Indian State of Orissa, New Delhi, November 2008, http://indianchristians.in/news/images/resources/pdf/2008_CLA_Orissa_Briefing_Paper. pdf (accessed 2011.09.02), p. 18.

${ }^{2}$ Asian Forum for Human Rights and Development (FORUM-ASIA), Fact Finding Report. Human Rights Violations Resulting from Religious Violence in Orissa, India, Bangkok, August-October 2008, http://www.forum-asia.org/news/press_releases/pdfs/Orissa\%20FF-Report. pdf, (accessed 2011.09.02), p. 22. Catholic Bishops' Conference of India, Report of CBCI Commission for Justice, Peace and Development, http://storage.paxchristi.net/2008-0745-en-apRV.pdf (accessed 2011.09.02), p. 5. The Interim Report of the Concerned Citizens'Independent Fact-finding Mission to Kandhamal (Orissa), "Mainstream" 2008, vol. XLVI No 42, http://www. mainstreamweekly.net/article965.html (accessed 2011.09.02). 
The Indian Christians collected evidence of attacks and eyewitness testimonies on their own but from the beginning they insisted on making reliable assessment by the state and national authorities and conducting independent investigation by the $\mathrm{CBI} .{ }^{3}$ In spite of these appeals, to examine the Orissa issue one-man commission under the retired judge Sarat Chandra Mohapatra was appointed. Till now (three years after the events), the commission has not submitted any report. The victims of the attacks do not believe that the judge is able to conduct an independent investigation. ${ }^{4}$ They do not trust the state authorities and local judiciary, which are associated with the circles inspiring the attacks. ${ }^{5}$ The vice-chairperson of the National Commission for Minorities held a tree-day visit to the riots affected area. The result of his visit was a several page report that contains general guidelines for the state and national authorities rather than objective data. ${ }^{6}$

In August and the beginning of September 2008, non-governmental organizations created teams to collect directly on-site data of the events and from eyewitness living in refugee camps. ${ }^{7}$ The task was not easy. In the initial period of riots, the most affected areas were not accessible due to transport obstacles and restrictions imposed for safety reasons. The team members had restricted access to the refugee camps. What is more, they faced violations and were threatened. ${ }^{8}$ Despite these difficulties they collected huge material containing

3 J. Malhotra, CBI probe into Orissa violence argued, "Christian Today" 30 April 2010, http://in.christiantoday.com/articles/cbi-probe-into-orissa-violence-urged/5318.htm (accessed 2011.09.02). D. Panda, Communal Violence in Orissa: Hindu Fundamentalist attack minority Christians, http://www.sacw.net/article61.html (accessed 2011.09.02), p. 2. Society for Threatened Peoples, Persecution of Christians in the Indian Federal State of India. Report of an investigation team of the Society for Threatened Peoples, Gottingen 2008, http://www.indianet.nl/pdf/ PersecutionChristiansOrissa.pdf (accessed 2011.09.02), p. 16.

${ }^{4}$ Orissa victims boycott inquiry, "Cathnews" 20 January 2010, http://www.indianet.nl/pdf/ PersecutionChristiansOrissa.pdf (accessed 2011.09.02), N. Carvalho, Bishop of Orissa: 'I have no faith' in the justice of the state, "Asia News" 22 October 2008, http://www.asianews.co.uk/ news-en/Bishop-of-Orissa:-I-have-no-faith-in-the-justice-of-the-state-13549.html (accessed 2011.09.02). R. Cheenath, Statement on the Orissa Violence on 22 September 2008, www.fides. org/eng/...STATEMENT_ON_THE_ORISSA_VIOLENCE.doc (accessed 2011.09.02), pp. 1-2. Christian Legal Association, op. cit., p. 10.

${ }^{5}$ People's Manifesto Orissa. Adivasis and Dalits of Kandhamal speak out!, http://www.jesaonline. org/images/stories/People\%27s\%20Manifesto\%20-\%20Orissa.pdf(accessed 2011.09.02), p. 6.

${ }^{6}$ National Commission for Minorities, NCM Report on the Visit of the Vice Chairperson NCM to Orissa $-11^{\text {th }}$ to $13^{\text {th }}$ September, 2008, http://ncm.nic.in/Tour-Reports.html (accessed 2011.09.02), p. 1.

${ }^{7}$ D. Panda, op. cit., p. 4.

${ }^{8}$ The Interim Report..., op. cit. and D. Panda, op.cit, p. 4. Asian Forum for Human Rights and Development, op. cit., p. 25. Catholic Bishops' Conference of India, op. cit., p. 2. Society for Threatened Peoples, op. cit., p. 8, Red Cross Society, Civil Society Organizations' Fact Finding Team Observations and Recommendations about continued violence in Kandhamal, Orissa, 
testimonies, interviews and their own observations. Among the NGOs engaged in these efforts there are organizations directly connected with Christian churches ${ }^{9}$ and other institutions fighting for human rights or associating public trust people like scholars, lawyers, social activists, etc. ${ }^{10}$ This paper is an attempt to compare the data from various reports and official statistics. It is worth noting that the records of the NGOs give a quite coherent picture of the events.

\section{The background of the conflict}

In India attacks on Christians are not a new phenomenon but the range of the last Orissa events was unprecedented in the history of Indian Christianity. ${ }^{11}$ According to the Asian Centre for Human Rights it was "the single largest attack on any religious group in the world in 2008."12

The history of after-independence communal tensions in Orissa indicates their strong correlation with the activities of the right-wing Hindu organizations such as the RSS, the VHP, Bajrang Dal, the BJP and others in that area. ${ }^{13}$ Even

presented in Bhubaneswar, on press release on 19 September 2008; available from: http://www. indianet.nl/pb080919.html (accessed 2011.09.02), § 2.

${ }^{9}$ Janvikas, Red Cross Society, Evangelical Fellowship of India [EFI], All India Christian Council [AICC], Christian Legal Association [CLA], non-Indian: Open Doors, Humanitarian Aid Relief Trust.

${ }^{10}$ Society for Threatened Peoples [GfbV], Asian Forum for Human Rights and Development (FORUM-ASIA), Human Rights Law Network [HRLN], Asian Center for Human Rights [ACHR],

National Campaign on Dalit Human Rights [NCDHR], Indian People's Tribunal on Environment and Human Rights.

${ }^{11}$ As for the Asian Center for Human Rights, 'Union Minister of State for Home Affairs, Mr Shakeel Ahmad announced that Orissa is state with the highest rate of communal violence in 2008. For total number 695 cases in India 159 occurred in Orissa.' See: Asian Center for Human Rights, Indian Human Rights Report 2008, New Delhi 2008, http://www.achrweb.org/reports/ india/AR08/AR2008.pdf (accessed 2011.09.02), p. 152. See also: The Interim Report..., op. cit.

${ }^{12}$ Asian Center for Human Rights, Indian Human Rights Report 2009, New Delhi 2008, http://www.achrweb.org/reports/india/AR09/AR2009.pdf (accessed 2011.09.02), p. 153.

${ }^{13}$ First communal riots in Orissa took place in the 1960s in Rourkela (1964) and Cuttuck (1968). Muslims were victims of those attacks. In 1967 Arya Samaj, RSS and VHP activists attacked the Christian community in Bertampur Town. Between 1986-87 in the Kandhamal District around 20 churches were burnt. Single attacks were reported in 1993. Five years later 5,000 activists of Sangh Parivar attacked the Christian villages in the Gajapati District. In 1999, the Australian missionary Graham Staines and his two sons were burnt to death. In September the Catholic priest Arul Das was killed. In the same year the Catholic nun Jacqueline Mary was raped. In March, Hindu activists burned 157 Christian houses and severely wounded 12 people. In 2004, seven women and clergyman were attacked in the Jagatsinghpur District. In 2005, the Baptist pastor Gilbert Ra and the Pentecostal pastor Dilip Dalai were tortured and then killed. See more: P. Kanungo, Hindutva's Entry into a 'Hindu Province': Early Years of RSS in Orissa, "The Economic and Political Weekly," August 2, 2003, http://www.sacw.net/DC/ CommunalismCollection/ArticlesArchive/Kanungo2003.html, (accessed 2011.09.02). History of attacks on Christians in Orissa, http://www.jesaonline.org/features/Orissa (accessed November 
during the partition the state remained free from communal violence, which was rare in other parts of the country. The first attacks on minorities in that area took place in the 1960s when the RSS and the VHP came into operations in Orissa. The tensions between religious communities increased during special actions of the right-wing alliance, e.g., attacks on Muslims in the sixties started with a support campaign for the Orissa Prevention of Cow Slaughter Act 1960 leading by the right-wing activists. In the same manner before the implementation of the Orissa Freedom of Religion Act 1967 Christians became the subject of attacks. ${ }^{14}$ Furthermore, in the 1990s more cases of attacks on Christians were reported in that area according to the BJP note concerning an increasing support on the national level. ${ }^{15}$

The direct prelude to the events of August 2008 was the attacks on Christians during the Christmas of 2007. However, even before that there were sufficient alarming signals. In 2006, the Indian People's Tribunal on Environment and Human Rights created a report, which says, "The inculcation of hatred toward minorities in Orissa is deep, so much so that, in the event of another massacre, there will be little hesitation in the execution of the most brutal acts." 16 The anti-Christian and anti-Muslim campaigns of hatred conducted over the years by Hindu organizations created a sense of threat from the minority communities in the minds of local people. ${ }^{17}$ For years Sangh Parivar leaders have spoken about a dangerous rapid growth of the Christian and Muslim population, using false statistics. They have presented missionary activities as dangerous for the indigenous culture and accused them of forced conversions..$^{18}$ Meanwhile, since

28, 2008), and A. Chatterji, Hindutva's Violent History, "Tehelka Magazine” 2008, vol. 5 no. 36, http://Tehelka.Com/Story_Main40.Asp?Filename=Ne130908hindutvasviolenthistory.Asp (accessed 2011.09.02).

${ }^{14}$ P. Kanungo, op. cit. A. Chatterji, Kandhamal: Hindutva's terror. Charting the history of Sangh Parivar violence in Orissa, p. 12-13, "The Economic and Political Weekly," August 2, 2003, http://www.sacw.net/DC/CommunalismCollection/ArticlesArchive/Kanungo2003.html (accessed 2011.09.02).

${ }^{15}$ The Indian People's Tribunal on Environment and Human Rights, Communalism in Orissa. Report of the Indian People's Tribunal on Environment and Human Rights, September 2006, http://www.iptindia.org/wp-content/pdf/report/COMMUNALISM-IN-ORISSA.pdf (accessed 2011.09.02), p. 3 and 53. Asian Forum for Human Rights and Development (FORUM-ASIA), op. cit., p. 8.

${ }^{16}$ The Indian People's Tribunal..., op. cit, p. 7.

${ }^{17}$ Catholic Bishops' Conference of India, op. cit., p. 3. The Society for Threatened Peoples, op. cit., p. 18.

${ }^{18}$ A. Chatterji, op. cit, pp. 12-13, Asian Forum for Human Rights and Development (FORUM-ASIA), op. cit., p. 8., pp. 8-9. Janvikas, Kandhamal in Chaos: An Account of

Facts, Ahmedabad 2009, http://janvikas.in/download/Kandhmal_in_chaos.pdf at 15 (accessed 2011.09.02), p. 11. 
the introduction of the Orissa anti-conversion law in the 1960s up no one has been sentenced under this act up till now. ${ }^{19}$

As reports emphasise, apart from the long-term propaganda of the Hindu fundamentalist groups an additional factor conducive to the development of communal tensions in Orissa is the socio-economic situation in the region. ${ }^{20}$ It fosters corruption and creates criminogenic links between politicians, local businesses and the criminal underworld. Orissa's land shape and inaccessibility forms an image of the region as terra incognita. ${ }^{21}$ Nowadays it is one of the poorest regions in India. A large part of the society is the population belonging to the so-called Scheduled Tribes (ST) and Scheduled Castes (SC) - groups exposed to social and economic discrimination. According to the 2001 Census, in Orissa they made up around 14 million (36\%). In that group there are 8,145, 081 $(22.1 \%)$ people with the ST certificate. $94.5 \%$ of them live in villages and only $15 \%$ work outside agriculture. ${ }^{22}$ The tribal population is located mainly in the hilly and jungle areas and is concentrated in two belts - in the north (districts: Majurbhanj, Keonjahr, Sundargarh) and in the south (Koraput, Ganjam, Phulbani). ${ }^{23}$ The statistical data show a high poverty rate and low education level among them..$^{24}$ The Scheduled Casts population in Orissa is 6, 082, 063 , constituting $16 \%$ of the total population. ${ }^{25}$ As for the Scheduled Tribes, they also live mainly in villages $(88.4 \%)$ and suffer from limited development opportunities. According to Sathianathan Clarke, the areas (like Orissa) inhabited by the Adivasis and Dalits are more often places of communal riots inspired by Hindu fundamentalists. ${ }^{26}$ But as mentioned above, the poor and backward population susceptible to influences is just an additional factor of tensions in Orissa. The necessary condition was long-term activities of the organizations

${ }^{19}$ The Indian People's Tribunal..., op. cit, pp. 12. 47-48. National Commission for Minorities, op. cit., p. 3. The Society for Threatened Peoples, op. cit., p. 18.

${ }^{20} \mathrm{~J}$. Vincent Manoharan, Report on the 2nd pressure building team organized by FJPK to respond to the attack on Dalit and Tribal Christians in Kandhamal in Orissa, 19 September 2008,

http://www.ncdhr.org.in/latestinterventions/report-on-the-2nd-pressure-building-team-organized-by-fjpk-to-respond-to-the-attack-on-dalit-and-tribal-christians-in-kandhamal-in-orissa (accessed 2011.09.02). Interim Report..., op. cit.

${ }^{21}$ P. Kanungo, op. cit.

${ }^{22}$ Orissa Data Highlights: The Scheduled Tribes. Census of India 2001, Ministry of Home Affairs, Office of the Registrar General, available at: http://censusindia.gov.in/Tables_Published/ SCST/dh_st_orissa.pdf (accessed 2011.09.02).

${ }^{23}$ S. C. Bhatt, Gopal K. Bhargava, eds. Land and people of Indian states and union territories: in 36 volumes: Orissa, New Delhi 2006, vol. 21, p. 15.

${ }^{24}$ The Indian People's Tribunal..., op. cit., p. 14.

${ }^{25}$ Orissa Data Highlights: The Scheduled Casts. Census of India 2001, Ministry of Home Affairs, Office of the Registrar General, India, available at: http://censusindia.gov.in/Tables_Published/SCST/dh_sc_orissa.pdf (accessed 2011.09.02).

${ }^{26}$ S. Clarke, Hindutva, Religious and Ethnocultural Minorities, and Indian-Christian Theology, "The Harvard Theological Review" 2002, vol. 95 no. 2, p. 207. 
affiliated to Sangh Parivar. ${ }^{27}$ Also the HRLN opposes overestimating the role of economic factors, writing, 'In fact, $96 \%$ of the victims of the violence are illiterate and there is no evidence that, once converted people gain any economic advantage over their Hindu neighbors. ${ }^{28}$

According to the authors of the Society of Threatened Peoples' reports, a proof of that is the fact that in regions with the same or even a greater prevalence of SC and ST and less operation of the Hindutva activists there are no conflicts on religious ground. ${ }^{29}$ The significant impact of fundamentalist propaganda and the fact that Christians were the only victims of the August attacks - according to the authors of the reports - indicate clearly the primarily religious nature of the conflict. ${ }^{30}$ In the interim report prepared by the Concerned Citizens Independent Fact-Finding Mission it is written, 'We saw several villages with Christian houses gutted but did not see any Hindu houses that were gutted. Several churches were extensively damaged. This also shows the intensity and nature of the one-sided orchestrated attacks. ${ }^{31}$

But the nature of the Orissa events remains still controversial in India. Some media and officials suggest that riots did not have a religious but ethnic background with the main role of Kui-Pana conflict. ${ }^{32}$ Moreover, in his statement

${ }^{27}$ D. Panda, op. cit. Human Rights Law Network, Ethnic Cleansing of Christians by Hindutva Rightwing Forces in Orissa, http://www.idsn.org/uploads/media/Orissa_report_-_Human_Rights_Law_Network.pdf (accessed 2011.09.02), p. 2. Humanitarian Aid Relief Trust, HART Visit to Orissa, India, October $30^{\text {th }}-$ November $4^{\text {th }} 2008$, http://www.hart-uk.org/advocacy/ hart_visitreport_india_08.pdf (accessed 2011.09.02), p. 12. Janvikas, op. cit., p. 10. NCM does not mention directly Sangh Parivar but 'extremist elements' propaganda, see: the National Commission for Minorities, op. cit., p. 6. People’s Manifesto..., op. cit., pp. 3-4.

${ }^{28}$ Human Rights Law Network, op. cit., p. 4.

${ }^{29}$ The Society for Threatened Peoples, op. cit., p. 15.

${ }^{30}$ The National Commission for Minorities, op. cit., pp. 1. 4. The Human Rights Law Network, op. cit., p. 1.

The Indian People's Tribunal..., op. cit., p. 3. The Interim Report..., op. cit.; the Society for Threatened Peoples, op. cit., p. 15; the Humanitarian Aid Relief Trust, op. cit., p. 6.

31 'The Kandhamal violence is not an ethnic conflict, it is clear case of fascist attack by the Hindu fundamentalist forces, abetted by the trading community, who are the traditional supporters of the Sangh Parivar, said a study team led by Mr P Vara Rao of Andhra Pradesh Revolutionary Writers Association', see: Hindu fundamentalists behind riots, ' 'Statesman", November 18, 2008, following: Minorities: Christians 2008, Documentation compiled by K. Samu, the Indian Social Institute, available at: http://www.isidelhi.org.in/hrnews/HR_THEMATIC_ISSUES/Christians/ Christians-2008.pdf, (accessed 2011.09.02), p. 64.

${ }^{32}$ Open Doors, Orissa state, India. An ongoing injustice: Christians facing death, violence and discrimination, 2009, http://www.opendoorsuk.org/advocacy/Orissa_Briefing_Paper.pdf (accessed 2011.09.02), p. 2. Reservation, not religion, root cause of Orissa riots, "Gulf Times," 1 January 2008, http://www.gulf-times.com/site/topics/article.asp?cu_no=2\&item_no=193131\&version=1\&template_id=40\&parent_id=22 (accessed 2011.09.02). S. Mohanty, Hindus vs. Christians or Kandhas vs. Panas?, "DNA - Daily News and Analysis", http://www.dnaindia.com/india/ report_hindus-vs-christians-or-kandhas-vs-panas_1195877 (accessed 2011.09.02). L. Kahar, 
on Orissa riots the former president of the BJP Venkaiaha Naidu underlined socio-economic and ethnic factors..$^{33}$ Other leaders of Sangh Parivar declared repeatedly that the conflict was a natural and spontaneous reaction of the local people towards the murder of Swami Laxmanananda Saraswati. ${ }^{34}$ Subhash Chouhan, the leading representative of Bajrang Dal, said in his interview, 'We don't have a single office in Kandhmal. [...] This is a reaction of the people against unfairness and excess perpetrated by the Christians. As I said, we have nothing to do with it. ${ }^{35}$

\section{Sequence of events}

The August wave of violence against Christians in Orissa was sparked off after the assassination of Vedanta Keshari Swami Laxmanananda Saraswati (originally named Lakshman) and his four followers in Jalespata Kanya Ashram in the Kandhamal District on the evening of 23 August 2008. Born in 1924, Swami was a life member of the RSS (Rashtriya Swayamsevak Sangh - the National Volunteer Organization). In the 1960s he left his home village Gurujanga and family (wife and one-year old son) and after a few years spent in the Himalayas, Swami arrived in Orissa to take a part in the anti-cow slaughter movement. In 1969 he founded his first ashram - in Chakapada (Kandhamal) and provided a social service among local tribes, established numerous schools and promoted the Hindu cultures. ${ }^{36}$ Laxmanananda was also involved in the anti-conversion campaign. He led the 'ghar vapasi' (homecoming) program - re-converting the natives who had received Christianity. ${ }^{37}$ In the opinion of the members of the Concerned Citizens' Independent Fact-Finding Mission Laxmanananda

Spurned tribals to intensify fight against Odisha government, Orissadiary.com, http://www. orissadiary.com/inerview/Lambodhar\%20Kahar.asp (accessed 2011.09.02). For NGOs' view on the Pana-Kui conflict see, e.g., Asian Forum for Human Rights and Development (FORUM-ASIA), op. cit., p. 6.

${ }^{33}$ Press Statement by Shri M Venkaiah Naidu, Former President BJP on Orisssa and Karnataka, http://www.bjp.org/index.php?option=com_content\&view=article\&id=5926\&catid=68:press-releases\&Itemid=494, 6-10-2008 (accessed 2011.09.02).

${ }^{34}$ See comments of Ashoka Singhala, the head of international structures of VHP in the article: V. Simha,

In the name of God, "Tehelka Magazine" vol. 5 no. 36, http://www.tehelka.com/story_main40. asp?filename $=\mathrm{Ne} 130908$ CoverStory.asp (accessed 2011.09.02).

${ }^{35}$ A. Soondas, Kandhamal tribals caught in conversion crossfire, "Times of India," October 6, 2008, http://articles.timesofindia.indiatimes.com/2008-10-06/india/27913210_1_christian-tribals-kandhmal-tribals-hindus (accessed 2011.09.02).

${ }^{36} \mathrm{http}: / /$ swamilakshmananda.org/life.htm. See also: B. Rout, Native village mourns Swami Lakshmanananda, "New Indian Express," 25 August 2008, p. 5. The Human Rights Law Network, op. cit., pp. 7-8, Asian Forum for Human Rights and Development (FORUM-ASIA), op. cit., pp. 9-10.

${ }^{37}$ A. Chatterji, op. cit. 
was a very controversial figure. Before his assassination many criminal cases were pended against him. ${ }^{38}$ There were nine unsuccessful attempts against Swami's life. Two days before his assassination he reported to have received an anonymous threatening letter to the police and requested additional protection. ${ }^{39}$

Immediately, Duna Keshav Rao alias Azad, a leader of the Maoist People's Liberation Guerrilla Army, claimed responsibility for the murder on 9 September. Orissa's Naxal spokesperson Sabyasachi Panda confirmed it in his official statement. ${ }^{40}$ Both were charged with the crime. On 17 October the State Crime Branch of the Police affirmed the participation of Central Committee of Communist Party of India (Maoist) in Swamiji's murder. ${ }^{41}$ But the members of Sangh Parivar rejected those claims accused Christians of the crime, and promised revenge. ${ }^{42}$ On 25 August - the day of the funeral, Sangh Parivar announced a general strike across the state. Under the leadership of BJP, RSS and VHP the $150 \mathrm{~km}$ long procession with body of Laxmananada was organised. ${ }^{43}$ The NGOs underline the fact that along the route there were the largest numbers of acts of aggression against Christians ${ }^{44}$ Dhirendra Panda notes the lack of the state government response to the Sangh Parivar decisions. It recognises many serious failures of the authorities, like giving permission to participate in the funeral by Praveen Togadia, the International General Secretary of VHP involved in the Gujarat riots and having an entry ban to many states of India or one day after Swami's body was transferred by Nikhil Kumar Kanodia - the police superintendent who declared to calling Christians' persecutors to account. ${ }^{45}$

${ }^{38}$ Interim Report..., op. cit. Asian Forum for Human Rights and Development (FORUM-ASIA), op. cit., p. 9.

${ }^{39}$ Kandhamal Superintendent N. K. Kanodia admitted that the Swami refused to strengthen the protection. Laxmanananda Saraswati Rejected Govt Security: Kanodia, "Outlook India," 22 September, 2009, http://news.outlookindia.com/item.aspx?666568 (accessed 2011.09.02).

${ }^{40}$ D. Samuel, "We killed Swami Laxmananda" says top Maoist leader, "Christian Today," September 4, 2008,

http://in.christiantoday.com/articles/we-killed-swami-laxmananda-says-top-maoist-leader/2924.htm, (accessed 2011.09.02). S. Mishra, Top Maoists involved in Saraswati killing, say cops, "Times of India," May 9, 2011, http://articles.timesofindia.indiatimes.com/2011-05-09/ bhubaneswar/29524474_1_crime-branch-maoist-links-sabyasachi-panda (accessed 2011.09.02).

${ }^{41}$ Asian Forum for Human Rights and Development (FORUM-ASIA), op. cit., p. 5.

${ }^{42}$ D. Panda, op. cit.

${ }^{43}$ Ibid.

${ }^{44}$ National Commission for Minorities, op. cit., pp. 2-3. Human Rights Law Network, op. cit., p. 9. Christian Legal Association, op. cit., p. 9. Society for Threatened Peoples, op. cit., p. 16.

${ }^{45}$ D. Panda, op. cit. Society for Threatened Peoples, op. cit., p. 16. Janvikas, op. cit., p. 13. As for "Kalinga Times" suspension of Kanodia was associated with the lack of the reaction of the Kandhamal police on the request of Laxmananda to strengthen his security, the result of which was the assassination of Swami. See: "Kandhamal SP placed under suspension," "Kalinga Times," August 24, 2008, 
The scenario of attacks, described by witnesses in different reports, is the same. A mob consisting of several dozen to several hundred of people usually under the influence of alcohol armed with lathes, guns, axes, spears, knives, crowbars etc. came to the village. The attackers shouted the slogans, 'Jai Shri Ram' (Long life to Rama), 'Jai Bajrang Dal' (Long life to Bajrang Dal), 'Bharat Mata ki Jai' (Long life to Mother India), etc., calling 'If you remain Christians, we will kill you. ${ }^{\prime 6}$ Some of them wore saffron bands and flags. According to the victims, the mob was headed by the local RSS and Bajrang Dal activists or by some unknown outsiders probably the members of Sangh Parivar from the other districts and states. The attackers damaged and burnt Christians' houses, places of worship, institutions and convents. It was enough to smash the roof of a house and then a monsoon finished the act of destruction. Household equipment was removed outside, put in piles and set in fire. Domesticated animals were stolen or killed; crops were robbed or completely destroyed. ${ }^{47}$ During the clashes more than 4,000 Christian houses were affected. Following the state data exactly 4,818 houses were destroyed (including 1,428 completely damaged) ${ }^{48}$ According to the Christian sources approximately 4,104 houses and 50 places of worship (Red Cross $\left.{ }^{49}\right), 4,500\left(\mathrm{CLA}^{50}\right), 4,640\left(\mathrm{AICC}^{51}\right), 4,009$ $\left(\mathrm{CBCI}^{52}\right)$ and 4,640 $\left(\mathrm{GfbV}^{53}\right)$, more than 5,000 - $\left(\right.$ Open Doors ${ }^{54}$ and HART $\left.{ }^{55}\right)$ including 3,298 fully demolished (Janvikas ${ }^{56}$ ). The Janvikas records say that

http://www.kalingatimes.com/odisha_news/news/20080824-Kandhamal-SP-placed-undersuspension.htm\# (accessed 2011.09.02). But according to the reports and the journalist S. Wunderick the cause was the fact that Kanodia effectively counteracted previous communal clashes in the region. For details see: Susan Wunderink, Worse than Ever, "Christianity Today" vol. 52 no. 11, http:/www.christianitytoday.com/ct/2008/november/3.15.html?start=1 (accessed 2011.09.02).

${ }^{46}$ Humanitarian Aid Relief Trust, op. cit., p. 12. J. Vincent Manoharan, op. cit. Interim Report..., op. cit.

${ }^{47}$ D. Panda, op. cit. Christian Legal Association, op. cit., pp. 5-6, Catholic Bishops' Conference of India, op. cit., p. 3, p. 3. Society for Threatened Peoples, op. cit., p. 9-10. Human Rights Law Network, op. cit., p. 3. Humanitarian Aid Relief Trust, op. cit., pp. 12-13. Interim Report..., op. cit. Civil Society of Organizations in Orissa, op. cit., p. 4. Society for Threatened Peoples, op. cit., p. 17.

${ }^{48}$ Status Report on Relief, Rehabilitation \& Reconciliation Measures, available from: kandhamal.nic.in/main/km-relief/rehab.doc (accessed 2011.05.15).

${ }^{49}$ Red Cross Society, op. cit.

${ }^{50}$ Christian Legal Association, op. cit., p. 5.

${ }^{51}$ All India Christian Council, Annual Report - A report on activities of the AICC in 2008, March 3, 2009, http://indianchristians.in/news/images/resources/pdf/aicc_annual_report_2008. pdf (accessed 2011.05.15), p. 5.

${ }^{52}$ Catholic Bishops' Conference of India, op. cit., p. 2.

${ }^{53}$ Society for Threatened Peoples, op. cit., p. 8.

${ }^{54}$ Open Doors, op. cit., p. 3

${ }^{55}$ Humanitarian Aid Relief Trust, op. cit., p. 3.

${ }^{56}$ Janvikas, op. cit., p. 15. 
also around 100-250 religious institutions and 267 churches were damaged, ${ }^{57}$ according to the Open Door -250 churches ${ }^{58}$ the GfbV -151 churches, the AICC -149 churches and 13 schools, ${ }^{59}$ the HART -117 churches, ${ }^{60}$ the CLA -100 churches and 20 other institutions, ${ }^{61}$ the CBCI -96 churches and 14 priests' and nuns' residences and training centres ${ }^{62}$ and 130-140 shops and other businesses owned by Christians (HRLN $\left.{ }^{63}\right)$.

In their testimonies victims complained about the system of compensations. They criticized the amount of payment and maintained that in many cases the officials stated that their property was damaged partially when in fact, it was completely destroyed. ${ }^{64}$ In some cases the barrier for the authorized to receive their compensation was that it was paid to the bank account. ${ }^{65}$

In the eyewitness testimonies collected by authors of various reports there are a lot of stories about the attackers' brutality. The victims were threatened, beaten or injured. They included children, the elderly and the disabled. ${ }^{66}$ The Christians were burnt alive or cut into pieces. The crowd was extremely violent, particularly towards pastors, priests and nuns. ${ }^{67}$ They suffered tortures, were humiliated and killed. Probably the most publicised story is that of Sister Meena Barwa who was raped. She and the local priest were beaten, threatened by death, half-naked brought through the village while the police was watching. The reports show just two or three cases of rapes (including Sister Barwa). But the authors think that actually sexual abuse during the riots can be underreported because of shame and social stigma. ${ }^{68}$ In India the context of this phenomenon was described inter alia in the memories of Sankar Sen - the long-time police officer. ${ }^{69}$

${ }^{57}$ Janvikas, op. cit., p. 16.

${ }^{58}$ Open Doors, op. cit., p. 3.

${ }^{59}$ All India Christian Council, op. cit., p. 5.

${ }^{60}$ Humanitarian Aid Relief Trust, op. cit., p. 3.

${ }^{61}$ Christian Legal Association, op. cit., p. 5.

${ }^{62}$ Catholic Bishops' Conference of India, op. cit., p. 2.

${ }^{63}$ Human Rights Law Network, op. cit., p. 26. Open Doors, op. cit., p. 4.

${ }^{64}$ S. Uma, Kandhamal: The Law Must Change Its Course, New Delhi 2010, pp. 170-176. See also: Humanitarian Aid Relief Trust, op. cit., pp. 5-6 and Janvikas, op. cit., p. 19.

${ }^{65}$ Human Rights Law Network, op. cit., p. 22.

${ }^{66}$ D. Panda, op. cit. Catholic Bishops' Conference of India, op. cit., p. 3. Humanitarian Aid Relief Trust, op. cit., pp. 14-15. Janvikas, op. cit., p. 19. J. Vincent Manoharan, op. cit.

${ }^{67}$ Catholic Bishops' Conference of India, op. cit., p. 2. Society for Threatened Peoples, op. cit., p. 11.

${ }^{68}$ Human Rights Law Network, op. cit., pp. 8-9. 44. Asian Forum for Human Rights and Development (FORUM-ASIA), op. cit., p. 23

${ }^{69} \mathrm{~S}$. Sen, Trust with law enforcement and human rights: four decades in Indian police, New Delhi 2002, pp. 178-179. See also: Women Against Sexual Violence and State Repression, 
Over the course of the August events in Orissa, according to the official data 52 people were killed, including 38 dying in communal violence, Laxmananda Saraswati with his four followers and three other victims of the Naxal terror; two policemen and four people were killed during the police intervention. ${ }^{70}$ The relatives of the victims were paid compensations from the Chief Minister's Relief Fund and Central Scheme for Assistance to Victims of Terrorist and Communal Violence. The National Commission for Justice, Peace and Development of Catholic Bishops' Conference of India, based on the official statistics, reported 38 victims of the clashes. ${ }^{71}$ The other Christian organisations calculate 42 $\left(\mathrm{EFI}^{72}\right)$ or at least 58 victims $\left(\mathrm{CLA}^{73}\right)$ or at least 50 people $^{74}(\mathrm{SCSW})$. The Janvikas report said about 86 killings. ${ }^{75}$ The All Indian Christian Council reported approximately 120 victims, including six pastors and one priest. ${ }^{76}$ The Society for Threatened Peoples reports more than 60 killings ${ }^{77}$ and the HART $-65 .{ }^{78}$ But the reports of the authors underline that establishing an exact dead toll is not easy because of heavy migrations in that period and a great number of missing people's cases. ${ }^{79}$ The report of the CPI-ML relied on the confidential confession of the local official, maintains that as a result of the riots more than 500 people could have lost their lives. ${ }^{80}$ The Concerned Citizens' Independent Fact-finding Mission criticises the officials for 'improper collection and recording of data.' 81

According to the Society for Threatened People 'it is clear that the attackers were not concerned with deliberately carrying out massacres and killing a large number of people. In view of the encircling of the villages and the overwhelming

Sexual Assault of an Adivasi Woman by Orissa Security Personnel in Gajapati District - A Fact Finding Report, January 2011, http://sanhati.com/wp-content/uploads/2011/04/wssreport. pdf (accessed 2011.09.02).

${ }^{70} \mathrm{NCM}$ underline that the official data based just on the cases when a body was found and post-mortem was performed, but many bodies were lost - burnt or eaten by animals. National Commission for Minorities, op. cit., p. 4.

${ }^{71}$ Catholic Bishops' Conference of India, op. cit., p. 2.

${ }^{72}$ Evangelical Fellowship of India, Orissa Christian Persecution Fact-Finding Report of Evangelical Fellowship of India, September 2008, http://www.southasianconnection.com/ blogs/995/Orissa-Christian-Persecution-Fact-Finding-Report.html (accessed 2011.09.02).

${ }^{73}$ Christian Legal Association, op. cit., p. 5

${ }^{74}$ D. Panda, op. cit.

75 Janvikas calculates that there were about 86 killings. See: Janvikas, op. cit., p. 15.

${ }^{76}$ Open Doors also notes approximately 120 killings. See: Open Doors, op. cit., p. 3.

${ }^{77}$ Society for Threatened Peoples, op. cit., p. 8.

${ }^{78}$ Humanitarian Aid Relief Trust, op. cit., p. 3.

${ }^{79}$ Asian Forum for Human Rights and Development (FORUM-ASIA), op. cit., p. 17.

${ }^{80}$ Fact-Finding Report on Kandhamal Situation, "Liberation", November 2008, http://www. cpiml.org/liberation/year_2008/november/index.htm\#6 (accessed 2011.09.02).

${ }^{81}$ The Interim Report..., op. cit. 
number of attackers it would have been easy to kill very many Christians. But the attackers were mainly concerned with spreading fear and panic and driving out the villagers. ${ }^{82}$

The attacks forced Christians to leave their villages. Most of them took shelter in the nearby jungle rather than find a place in relief camps organised by the state government. ${ }^{83}$ There were also some private camps - set up by the Church or individuals. Various sources claim different amounts of the refugees. According to the Status Report on Relief, Rehabilitation $\&$ Reconciliation Measures there were 25,177 refugees in 10 camps (data on 4 September) ${ }^{84}$ NCM gives the number of $20,000^{85}$ and the Asian Centre for Human Rights maintains that 30,000 peoples were expelled. ${ }^{86}$ Christian sources speak about 40,000-50,000 refugees. In its annual report for 2008 the All Indian Christian Council gave 54,000 refugees, ${ }^{87}$ the Society for Threatened People $-53,000 .{ }^{88}$ the Human Rights Law Network, ${ }^{89}$ the Open Door, ${ }^{90}$ the $\mathrm{CLA}^{91}-5,000$. The government data could be underestimated because they include only the number of refugees stationed in the official camps. ${ }^{92}$ Whereas people who fled from persecutions were also located in the private camps, and as the reports evaluate a great part of them migrated to bigger cities and areas even out of Orissa.$^{93}$ In his summary made half a year after the August events Bishop Raphael Cheenath of Cuttuck-Bhubaneshwar said that as a result of the attacks more than 1,200 families changed their places of residence, 6,000 of the refugees lived in the Salisahi slums in Bhubaneshwar, some other worked in Andhra Pradesh, Kerala and Punjub. 200-300 families were still living in the private camps and more than 4,400 in tents, temporary shelters or makeshift houses. ${ }^{94}$ The Janvikas stated in May 2009 that 2,210 families were still living

${ }^{82}$ Society for Threatened Peoples, op. cit., s. 10.

${ }^{83}$ The Interim Report..., op. cit.

${ }^{84}$ Status Report on Relief, Rehabilitation \& Reconciliation Measures, Official Website of the Kandhamal District - kandhamal.nic.in/main/km-relief/rehab.doc

${ }^{85}$ National Commission for Minorities, op. cit., p. 2.

${ }^{86}$ Asian Center for Human Rights, Indian Human Rights Report 2009, op. cit., p. 153.

${ }^{87}$ All India Christian Council, op. cit., p. 5.

${ }^{88}$ Society for Threatened Peoples, op. cit., p. 3.

${ }^{89}$ Human Rights Law Network, op. cit., p. 10.

${ }^{90}$ Open Door, op. cit., p. 3

${ }^{91}$ Christian Legal Association, op. cit., p. 5

${ }^{92}$ Reports maintain that the unofficial sources can be closer to the truth. See: National Commission for Minorities, op. cit., p. 2, D. Panda, op. cit. National Commission for Justice Peace and Development, op. cit., p. 2.

${ }^{93}$ Women Against Sexual Violence and State Repression, op. cit., p. 15. Human Rights Law Network, op. cit., pp. 11-12. People's Manifesto..., op. cit., p. 6.

${ }^{94}$ Raphael Cheenath, For Orissa Bishop, reconciliation but also justice must follow the violence, "Asia News," July 2, 2010, 
in relief camps. ${ }^{95}$ The Open Doors estimates that approximately 4,000 refugees were still in camps in August 2009. ${ }^{96}$

The reports point out bad conditions in the relief camps - insufficient food, poor access to clean water or medical care and inadequate sanitation. ${ }^{97} \mathrm{In}$ one report the authors compare the Orissa relief camps to the Nazi concentration camps. ${ }^{98}$ As the HRLN noticed, 'There are no bathing facilities in any of the camps. Residents bathe in streams or reservoirs up to $2 \mathrm{~km}$ away. ${ }^{99}$ It caused severe hardship especially for pregnant women, elderly people and children as well as created conditions for many diseases - among others the most common diarrhoea and malaria, in some cases causing death. ${ }^{100}$

These omissions could be justified by the lack of material resources and treated as organisational shortcomings. But as the reports underline the lack of sense of security in the camps could not be treated as inadvertent. In September, 12,000 refugees left the camps for security reasons. 56 families moved to Kerala and requested for asylum there. ${ }^{101}$ On 20 September in the Tikabali relief camp a hunger strike raised over inadequate conditions and neglect of safety issues. ${ }^{102}$

The NGOs personnel as well as opposition parties' members were not allowed to enter the affected area. ${ }^{103}$ But the members of Sangh Parivar had permission to conduct (even in the relief camps) pro-Hindu campaigns and reconversion ceremonies called 'homecoming. ${ }^{104}$ The refugees pointed out that it was a very inadequate notion because a large part of the re-converted people had never

\footnotetext{
www.asianews.it/news-en/For-Orissa-bishop,-reconciliation-but-also-justice-must-follow-the-violance-17561.html (accessed 2011.09.02). Open Doors, op. cit., p. 4.

95 Janvikas, op. cit., s. 29.

${ }^{96}$ Open Doors, op. cit., p. 4.

${ }^{97}$ Human Rights Law Network, op. cit., pp. 11. 17-18. Catholic Bishops' Conference of India, op. cit., p. 4. Janvikas, op. cit., p. 14. Red Cross Society, op. cit., § 3-5. The Interim Report..., op. cit.

98 'The brutally substandard dietary and hygienic conditions of the camps apart from the state machinery with the help of the CRPF turned such refugee camps into concentration camps of the Nazi kind.' People's Manifesto ..., op. cit., p. 5.

${ }^{99}$ Human Rights Law Network, op. cit., p. 18.

${ }^{100}$ Ibid., p. 18. Catholic Bishops' Conference of India, op. cit., p. 4, J. Vincent Manoharan, op. cit.

${ }^{101}$ Human Rights Law Network, op. cit., p. 8. Society for Threatened Peoples, op. cit., p. 9, The Interim Report..., op. cit.

${ }^{102}$ Human Rights Law Network, op. cit., p. 44.

${ }^{103}$ National Commission for Minorities, op. cit., pp. 5. 7. Human Rights Law Network, op. cit., p. 9. Catholic Bishops' Conference of India, op. cit., p. 2. Janvikas, op. cit., p. 14. J. Vincent Manoharan, op. cit.

${ }^{104}$ National Commission for Minorities, pp. 1. 3. 4. Human Rights Law Network, op. cit., p. 13.
} 
been Hindu. Some of them had been followers of tribal religions but usually they had been simply Christians by birth. ${ }^{105}$

The reconversion ceremonies typically included the shaving of the head, making a tilak on the forehead, consuming five products of the cow: milk mixed with gee, curd, cow dung and urine, and worshipping the Hindu gods. But also other practices were described. ${ }^{106}$ However, the leaders of the ceremonies also demanded anti-Christian acts from the new believers, such as destroying the sacred objects, e.g., status, images, Bibles, and attacks on churches.

Most reconversions during that period were forced conversions using intimidation, violence or blackmail. ${ }^{107}$ The CBCI says that in some cases converts were offered payment in the amount of $1-1.5$ thousand rupees. ${ }^{108}$ Often accepting Hinduism was the only condition to leave the camp. But as the reports say one of the common practices in the camps was to force Christians to drop their charges before drawing out. ${ }^{109}$

The victims complained of ill-treatment by the local authorities. The police were often a silent witness to the assaults on Christians. ${ }^{110}$ The injured were denied to lodge complaints against the attackers and they were arrested under false encounters. Meanwhile the accused stayed free. ${ }^{111}$ According to the analysis presented in the reports, the state government was giving a silent approval stamp on all of these police actions. ${ }^{112}$ On 18 September the central government reminded that under Article 355 of the Indian constitution the state authorities had the duty to counteract internal tensions. ${ }^{113}$ In practice,

${ }^{105}$ Human Rights Law Network, op. cit., p. 14. Asian Forum for Human Rights and Development (FORUM-ASIA), op. cit., p. 6. Humanitarian Aid Relief Trust, op. cit., p. 13. The Interim Report..., op. cit.

${ }^{106}$ Human Rights Law Network, op. cit., p. 14. Catholic Bishops' Conference of India, op. cit., p. 4. Society for Threatened Peoples, op. cit., pp. 11-12.

${ }^{107}$ Evangelical Fellowship of India, op. cit., p. 11. Human Rights Law Network, op. cit., pp. 14-15, Asian Forum for Human Rights and Development (FORUM-ASIA), op. cit., p. 20. J. Vincent Manoharan, op. cit. The Interim Report..., op. cit.

${ }^{108}$ Catholic Bishops' Conference of India, op. cit., p. 2.

${ }^{109}$ National Commission for Minorities, op. cit., pp. 1. 3. 4, D. Panda, op. cit. Human Rights Law Network, op. cit., p. 13, Janvikas, op. cit., p. 10.

${ }^{110}$ D. Panda, op. cit. Human Rights Law Network, op. cit., pp. 2-3. 8. Society for Threatened Peoples, op. cit., p. 16. Red Cross Society, op. cit., $\S 1$.

${ }^{111}$ Human Rights Law Network, op. cit., pp. 14-16. 27-28. Asian Forum for Human Rights and Development (FORUM-ASIA), op. cit., pp. 16. 24-25. Catholic Bishops' Conference of India, op. cit., pp. 3-4. Society for Threatened Peoples, op. cit., pp. 13-14.

${ }^{112} \mathrm{NCM}$ complained the non-implementation of previous recommendations of NCM by the state government. See: National Commission for Minorities, op. cit., p. 7. See also: D. Panda, op. cit. Human Rights Law Network, op. cit. pp. 9-10. Humanitarian Aid Relief Trust, op. cit., pp. 5. 17. J. Vincent Manoharan, op. cit.

${ }^{113}$ Christian Legal Association, op. cit., p. 9. 
the situation normalised after the arrival of the Central Reserve Police Forces (CRPF) to Orissa. ${ }^{114}$

\section{Interpretation}

The riots in Orissa were quelled after more than two months. The members of the survey teams organised by the NGOs agree that it was a religious conflict, which was well prepared and conducted by the right-wing activists. ${ }^{115}$

The picture of the events depicted in the reports fits to the riot system described by Paul Brass who has studied the Hindu-Muslim clashes in Aligarh for more than 40 years. According to the scholar an attempt to recognise communal riots as spontaneous episodes is a mistake. 'Large-scale riots instead are productions that have, in fact, features of a grisly form of drama which, like theatrical dramas, occur in three phases. Those phases are preparation/rehearsal; activation/ enactment; and explanation/interpretation." 116 In a region sensitive to communal violent tensions among groups are raised on different levels by highlighting minor differences and then maintaining them by propaganda instruments. The initial incident that begins riots can be unexpected as the murder of Swami Laxmanananda, but it does not contradict the allegations that the pogroms were well-prepared. ${ }^{117}$ 'Some of the contributing evidence includes numerous reports of roads being blocked to ambush cars and prevent authorities from responding to on-going incidents; coordination among groups of attackers from outside the areas who moved from village to village, helped by village locals to identify targets; and correspondence received by victims warning them of potential violence against them and their homes.' ${ }^{118}$

Brass thinks that in the riots production system roles of different figures play defined roles. There are voluntary informants (who collect and spread information about incidents among hostile communities), rubble-rousers (whose task is to heat up the atmosphere of anger, mutual distrust and fear), people engaged in propaganda and contacts with the media, mob organisers, members of illegal groups, criminals as well as journalists, politicians, lawyers

${ }^{114}$ Society for Threatened Peoples, op. cit., p. 17. The Interim Report ..., op. cit

${ }^{115}$ Asian Forum for Human Rights and Development (FORUM-ASIA), op. cit., pp. 21-22. Catholic Bishops' Conference of India, op. cit., p. 3., Janvikas, op. cit., p. 14. Red Cross Society, op. cit. Civil Society of Organizations in Orissa, op. cit., p. 4.

${ }^{116}$ Paul Brass, Riots, Pogroms, and Genocide in Contemporary India: From Partition to the Present, Speech prepared for the Hiroshima Peace Institute Conference on Comparative Research into Genocide and Mass Violence, Hiroshima, Japan, March 22-26, 2004, available at: http:// www.paulbrass.com/riots_pogroms_and_genocide_in_contemporary_india_from_partition_to the presen_32432.htm (accessed 2011.09.02), p. 6 .

${ }^{117}$ D. Panda, op. cit.

${ }^{118}$ Asian Forum for Human Rights and Development (FORUM-ASIA), op. cit., p. 21. 
and scientists. The latter are particularly important in the last - interpretation phase - with the aim to move attention from processes of the riot production and to transfer responsibility.

All elements of riots mentioned by Brass appeared in the Orissa case: preparing, enacting, battle for interpretation as well as participation of different players - from all levels of politicians, the police, businessmen to the activists of the RSS and Bajrang Dal leading incited crowds. The dress rehearsal before the main performance was the attacks on Christians in December 2007, which were almost unnoticed by the public opinion. But this compatibility between the analysis of the Orissa riots, contained in the NGOs' reports, and Brass' scheme should be really alarming. Since he notices that in the case of communal clashes in India an interpretation phase overlapped with the preparation stage of the following attacks, it is just a matter of time until something happens. 